Journal of European Public Policy

\title{
Europe belongs to the young? Generational differences in public opinion towards the European Union during the Eurozone crisis
}

\section{Fabian Lauterbach \& Catherine E. De Vries}

To cite this article: Fabian Lauterbach \& Catherine E. De Vries (2020) Europe belongs to the young? Generational differences in public opinion towards the European Union during the Eurozone crisis, Journal of European Public Policy, 27:2, 168-187, DOI: 10.1080/13501763.2019.1701533

To link to this article: https://doi.org/10.1080/13501763.2019.1701533

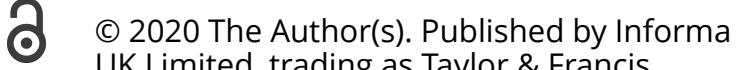
UK Limited, trading as Taylor \& Francis Group

+ View supplementary material $\square$

Published online: 30 Jan 2020.

Submit your article to this journal $\square$

Q View related articles $\sqsubset$

View Crossmark data ¿ 


\title{
Europe belongs to the young? Generational differences in public opinion towards the European Union during the Eurozone crisis
}

\author{
Fabian Lauterbach ${ }^{\mathrm{a}}$ and Catherine E. De Vries ${ }^{\mathrm{b}}$ \\ aDepartment of Political Science and Public Administration, Vrije Universiteit Amsterdam, \\ Amsterdam, The Netherlands; ${ }^{b}$ Department of Social and Political Sciences, Bocconi University, \\ Milano, Italy
}

\begin{abstract}
The notion that younger people hold more favourable attitudes towards the European Union (EU) is prevalent in both academic and popular discourse. While certain events like the Brexit referendum in the United Kingdom fit this intuition, other developments such as Eurosceptic parties garnering considerable support among millennial voters in some member states do not. To understand these diverging trends, this study draws our attention to how specific events shape EU support. It empirically demonstrates how the Eurozone crisis shapes generational divides. Younger cohorts in debtor countries have become significantly more sceptical of the EU than their peers in creditor states. The opposite pattern emerges for older cohorts. Older generations are more supportive of the EU in debtor countries compared to creditor states. These findings have important implications for our understanding of how public support for the EU will develop in the future by suggesting that generational divides are highly context-dependent.
\end{abstract}

KEYWORDS Public opinion; European integration; generations; Eurozone crisis; context

\section{Introduction}

The notion that younger people hold more favourable attitudes towards the European Union (EU) is dominant in both scholarly and popular discourse (e.g., Down and Wilson 2013, 2017; Fligstein 2008; Ford and Goodwin 2014; Keating 2014; Lubbers and Scheepers 2005, 2010). Much of the empirical evidence to date suggests that younger people are more likely to be positive about European integration. The reasons for this finding are manifold. Younger people are socialized in an increasingly integrated Europe (Down

CONTACT Catherine E. De Vries catherine.devries@unibocconi.it

(4) Supplemental data for this article can be accessed https://doi.org/10.1080/13501763.2019.1701533.

(c) 2020 The Author(s). Published by Informa UK Limited, trading as Taylor \& Francis Group

This is an Open Access article distributed under the terms of the Creative Commons Attribution-NonCommercial-NoDerivatives License (http://creativecommons.org/licenses/by-nc-nd/4.0/), which permits non-commercial re-use, distribution, and reproduction in any medium, provided the original work is properly cited, and is not altered, transformed, or built upon in any way. 
and Wilson 2013, 2017), and therefore less ideologically and affectively bound to national institutions and sovereignty (Scherer 2015). Younger cohorts are also characterized by higher levels of education and political sophistication, therefore possibly more post-materialist in their value orientations (e.g., Inglehart 1984), and less concerned about their national identity as a result (McLaren 2002). Recent developments in some member states fit the notion of a more supportive youth. Take the United Kingdom for example. In the 2016 Brexit referendum, about three-quarters of the 18-24-year-olds voted to remain in the EU. ${ }^{1}$ Yet, the picture of a more supportive youth becomes murkier when we consider recent developments in other member states, such as France and Italy for example. Rightwing Eurosceptic presidential candidate Marine Le Pen was more popular among young voters, those aged between 18 and 24, than Emmanuel Macron in the 2017 French presidential elections. ${ }^{2}$ Meanwhile in the 2018 parliamentary elections in Italy, over sixty per cent of millennial voters supported the two main Eurosceptic parties, the League and the Five Star Movement. ${ }^{3}$

How can we account for these different developments across member states? This study draws our attention to context. It suggests that the distinct experience a generation makes with the EU shapes intra-generational divides in EU support. To empirically illustrate how context may shape generational patterns in support for the EU, this study focuses on the Eurozone crisis. The Eurozone crisis erupted after the financial crisis broke out in the United States following the collapse of the investment bank Lehmann Brothers. In Europe, financial turmoil quickly turned into a sovereign debt crisis. By 2012, several EU member states had received some form of financial bailout. Youth unemployment was one of the most important channels through which the consequences of Eurozone crisis were transmitted differently across member states. Youth unemployment reached over $20 \%$ in the $\mathrm{EU}$ as a whole at the height of the crisis, and only slightly decreased to about $17 \%$ in 2017 . These numbers mask huge variation between debtor and creditor countries. Debtor countries, like Greece and Spain, entered the Eurozone crisis with youth unemployment rates of 23 and 18\% respectively, but as crisis took hold of their economies about one in two of young people became unemployed. In contrast, the youth unemployment rate in a creditor country like Germany, overall much less affected by the crisis, declined within the Eurozone crisis timeframe from about 12 in 2007 to $8 \%$ in 2013. In 2017, youth unemployment in Greece and Spain remained high, with $44 \%$ and $37 \%$ respectively, while in creditor countries, like Germany and the Netherlands, it was only about $8 \%$ and $9 \%$ respectively. European Central Bank president, Mario Draghi highlighted the significance of these persistent differences in a 2017 speech: 'the persistence and heterogeneity of youth unemployment across member states point to continued underlying 
problems in labour market structures, with correspondingly high costs for our societies'. 4

The experience with the Eurozone crisis differed tremendously across creditor and debtor states with considerable effects on public opinion and political behaviour (on the importance of crisis, see Lefkofridi and Schmitter 2015). What we do not know is how these different experiences shaped public support for the EU across generations. Existing work on generational divides stems largely from North Western Europe and fails to take into account the important ways in which generational divides differ across contexts. This study aims to remedy this lack of understanding by exploring generational divides based on the Eurozone crisis experience, i.e., being a debtor or creditor country. If, as we argue, generational effects differ based on the experience of the crisis, we should find very different generational patterns in support for the EU across creditor and debtor states. While we would expect generational divides to be quite similar before the crisis, they should diverge as the crisis kicks in. Specifically, we expect the differences between younger and older cohorts in debtor countries, that were worst hit in the crisis, to become less pronounced during the crisis compared to those in creditor countries and other member states that were overall less affected.

To our knowledge, this is the first study to systematically examine the context-dependent nature of generational differences in support for the EU. In doing so, it empirically tests the popular image of young Europhiles versus older Eurosceptics. By stressing the importance of how the Eurozone crisis affected age cohorts ${ }^{5}$ differently across member states, this study contributes to the broader literature on the causes and dynamics of public support for the EU. The results somewhat temper the widespread belief that Euroscepticism will gradually disappear simply with the passing of time and through generational replacement. The specific experiences that each generation makes with the EU will be crucially important.

This study proceeds as follows. First, we examine existing work on generational trends in public opinion towards European integration, distinguish key issues that we think require further examination, and outline how this study aims to fill current gaps in our understanding. Second, we provide an overview of the data and method used to examine generational divides. Third, we present the results of the empirical analysis. Finally, we conclude by highlighting the importance of these findings.

\section{Generational trends in public opinion towards European integration}

Public opinion towards European integration has enjoyed extensive academic attention over the years (Hobolt and De Vries 2016). One key topic in scholarly work has been generational differences in support for European integration. 
As early as 1971, Ronald Inglehart introduced the notion that younger generations should be more supportive of European integration. Based on the idea that the youth is more likely to adopt post-materialist value orientations, Inglehart (1971: 1) expected them to 'be much less nationalistic, and perhaps relatively ready to surrender some of their national sovereignty to European political institutions'. Younger generations were more likely to approve of the EU's normative role in international politics more generally (Inglehart 1984).

The notion that younger people hold more favourable opinions about the EU is dominant in the literature (e.g., Down and Wilson 2013, 2017; Fligstein 2008; Ford and Goodwin 2014; Keating 2014; Lubbers and Scheepers 2005, 2010). Two key mechanisms have been put forward to account for generational differences: one rooted in education and one in socialization. Higher educational attainment is generally seen as a key factor in creating more support for the EU (Gabel 1998). Research suggests that increased educational attainment may not only make larger proportions of the youth comprehend the EU better, but also allows them to benefit more directly from the common market and economic liberalization within Europe (Hakhverdian et al. 2013). Moreover, rising levels of education are associated with higher levels of political sophistication that makes people more aware of the benefits of increased political and economic cooperation in Europe (Fox and Pearce 2018).

Next to education, socialization is also viewed as important. In their pioneering work on generational divides, Down and Wilson $(2013,2017)$ suggest that successive cohorts have become more supportive of European integration because they were socialized in a gradually weakened nation state. Therefore, they accepted the division of competencies between the EU and national institutions. Analyzing age and generational effects in Western European member states from the late 1970s and 1980s up to 2008, the authors suggest that EU support is most pronounced among the younger generations, but decreases over the life course. They argue that, because integration has been largely unidirectional and has never been really been reversed (before Brexit that is), successive generations were socialized in an economic and political environment characterized by higher levels of integration, and progressively less national autonomy. As a result, younger generations should be more positive about further integrative steps (Down and Wilson 2013, 2017). Each new age cohort socialized in a time where the EU is more influential, is expected to view the prevailing power relation between EU and nation state as a given, and is therefore less likely to question the integration process.

Due to this socialization process, younger generations are also expected to be less concerned about a loss of national sovereignty, a major driver of Euroscepticism (McLaren 2002). Given that European integration involves a 
transferral of competencies from the national to the European level, the EU is highly unattractive to individuals who exhibit strong and exclusive national identities (Hooghe and Marks 2009; McLaren 2002). Due to the fact that younger generations have been socialized in an era of increased internationalization, they are expected to display less nationalist sentiments (e.g., Jung 2008; Wilson 2008, 2011) and be more supportive of EU membership as a result (Ford and Goodwin 2014; Keating 2014).

To sum up, based on the existing literature younger generations are expected to be more pro-EU compared to older ones due to three intertwined processes: (1) rising levels of education and political sophistication among the young coincides with more EU support; (2) being raised in an age where European institutions and policy making is prevalent normalizes the integration process and decreases the attachment of younger cohorts to domestic political and economic institutions; and (3) through a process of increased European cooperation feelings of exclusive national identity are less prevalent among younger cohorts.

These theoretical conjectures and empirical findings are crucially important, but also leave several key questions unaddressed. First, while education and socialization are clearly crucial in shaping public opinion toward the EU, would we also not expect specific experiences to matter? People's experiences with the EU are rooted in large-scale events, like the Eurozone crisis, and the consequences of these events differ widely across generations and member states. Therefore, it seems reasonable to expect that these events shape generational divides in EU support. Second, how do we square the idea of younger generations being pro-EU with rising Eurosceptic party support among the young in for example France and Italy? Much of our understanding of the generational trends in support for the EU is obscured by the fact that the empirical evidence to date is almost exclusively based on North Western European member states. It fails to appropriately account for regional differences and the rising proportion of young Eurosceptics, especially in the South. This may be especially problematic when we wish to examine how crises affect generational divides in public opinion towards the EU.

We maintain that existing work on generational divides has paid too little attention to the ways in which experiences of generations with the EU shape public opinion towards the Europe. Generational divides differ tremendously across member states and affect the young and old differently. As a result, we expect generational patterns in EU support to differ based on context. We illustrate this by examining how the Eurozone crisis shaped generational divides in public opinion towards EU, and how this effect varies across creditor and debtor states. Recent work has suggested that public opinion towards the EU varies across regions (Lubbers and Scheepers 2005, 2010; Otjes and Katsanidou 2017) and national contexts (De Vries 2018). The Eurozone crisis led to 
starkly different levels of youth unemployment across member states. Creditor countries in the North experienced a small economic upset that did not translate into massive youth unemployment, while debtor countries, especially those in the South of Europe, experienced the bulk of adverse effects and a sharp rise high youth unemployment. In Spain for example almost one in two below 30-year-olds became unemployed. ${ }^{6}$ These starkly different experiences, we argue, frame how people in general and different generations in particular view the EU (e.g., De Vries 2018). While not explicitly focusing on generational differences, Daniele and Geys (2015) suggest that in Euro-debtor states, like Cyprus, Greece, Italy, Portugal, and Spain, younger people are less supportive of further integration than their western counterparts, while the opposite holds for older people. If generational effects differ across contexts, as we argue here, we should find very different generational divides in support for the EU in creditor and debtor states.

\section{Method and data}

Research on the effects of age on political attitudes in general distinguishes between three distinct effects: life-cycle, period, and cohort effects. In simple terms, life-cycle effects encompass the impact of the various stages in life, such as childhood, adolescence, adulthood, midlife and so on. Period effects refer to the contextual effects of time that affect everybody in a given population and regardless of their age. Cohort effects reflect the conditions in which individuals are socialized at a given time and that result in distinctive political traits. The starting point for the estimation of life-cycle, period, and cohort effects is typically the Age- Period-Cohort (APC) model (Yang and Land 2016). The well-documented problem with these models is that only two of these effects can be identified as age (years since birth), period (year), and cohort (year of birth) are exact linear functions of each other (see also Neundorf and Niemi 2014).

Based on existing work we rely on three ways in which researchers have tried to overcome this problem. First, we use a coefficient constraint approach that involves the transformation of one of the variables that ought to measure one of the three effects of time from an interval into a categorical variable, thereby resolving the problem of shared linear dependence (e.g., Yang et al. 2004). Specifically, we group individuals born across adjacent years into cohorts. Cohorts are defined as a group of people who share a specific bracket of years in which they were born, and thus share certain formative experiences (they are also generally referred to as generations). Our second approach to estimate cohort effects relies on a difference-in-difference analysis in which we interact the fact that a country was either a creditor or debtor country in the crisis with the age cohorts. ${ }^{7}$ The crux of our argument is that experiences with the Eurozone crisis were very different for same-year 
cohorts in creditor and debtor member states. Differentiating between these two groups allows for a more reliable identification of cohort effects and their regional variation because it enables us to estimate generational differences with between-cohort as well as within-cohort comparisons (see Dinas and Stoker 2014). Our third approach tries to capture the way the Eurozone crisis in shaped cohort effects by differentiating spatial and temporal variations. More specifically, we distinguish between cohort effects in (1) creditor and debtor member states before 2008, (2) during the actual crisis period (2008-2012), and (3) in the crisis period (2008-2012). We did not include the post-2012 period in an effort to isolate experiences with the Eurozone crisis from those more recent ones, most notably the large influx of refugees. Non-creditor and non-debtor member states are used as reference category. This allows us to examine whether potential (intra-) generational differences among creditor and debtor cohorts are attributable to the Eurozone crisis.

In all three approaches we need to define distinctive groups of birth year cohorts defined based on theoretical considerations prior to the analysis. Given that time-related change is often subtle, meaningful cohort boundaries to indicate political generations make more sense between individuals with temporally distant socialization experiences (Jennings et al. 2009). Yet, the categorization of generational units based on common socio-historical experiences raises the issue of potentially arbitrary boundaries. This obviously risks selection bias and results that are not meaningful if the categorization is not rooted in well-founded theoretical considerations. We ground our categorization of cohorts in the work of Down and Wilson $(2013,2017)$, see Table 1. These authors argue that the EU's historic development itself is important in defining relevant generations in the European context. Two aspects of the integration process are crucial in this respect: integration has been unidirectional (i.e., progressively more over time) and that public resistance to it is primarily shaped by the concern about the associated loss of national autonomy (Down and Wilson 2013, 2017). While their argument is theoretically sound, it appears problematic that their operationalization is based on when individuals' come of age (i.e., when they turn 15), despite the contemporary consensus in the field of political socialization that meaningful early adulthood socialization takes place at least until the early twenties (e.g.,

Table 1. Overview of cohorts based on the development of European Union.

\begin{tabular}{|c|c|c|}
\hline Cohort & $\begin{array}{l}\text { Birth year } \\
\text { clusters }\end{array}$ & Cohort-unique feature \\
\hline Pre-integration & before 1933 & No considerable cooperation or trans- or supranational integration \\
\hline Post-integration & 1933-1945 & Initial cooperation and integration of Western European countries \\
\hline Merger & 1946-1966 & Establishment of the European Communities with the Merger Treaty \\
\hline SEA & 1967-1972 & $\begin{array}{l}\text { Establishment of the single European market following the Single } \\
\text { European Act }\end{array}$ \\
\hline $\begin{array}{l}\text { Post-Maastricht } \\
\text { Euro / EMU }\end{array}$ & $\begin{array}{l}1973-1979 \\
\text { after } 1979\end{array}$ & $\begin{array}{l}\text { Establishment of the European Union following the Maastricht Treaty } \\
\text { Introduction of the Euro as common currency }\end{array}$ \\
\hline
\end{tabular}


Grasso 2014; Jennings 2007; Jennings et al. 2009). Respondents were therefore categorized into one of the following six cohorts depending on whether they reached age 20 (1) before the first European states embarked on the process of unification with establishment of the European Coal and Steel Community in 1952, (2) before the Merger Treaty that established the European Communities in 1965, (3) before the Single European Act (SEA) of 1986, (4) before the Maastricht Treaty that laid the foundation for the present-day EU in 1992, (5) before and (6) after the creation of the European Monetary Union (EMU) in 1999. These are all perceived as key turning points in European integration and formative for different cohorts (Down and Wilson 2013, 2017).

For the empirical analysis, we merged individual-level data from the 20022016 rounds of the European Social Survey (ESS). The ESS is one of the most methodologically rigorous regional cross-national survey projects. It was initiated in 2002 and since then many more waves were conducted in twoyear intervals. The ESS especially aims to reduce the heterogeneity in survey practices across countries. This harmonization of standards is important as it allows us to reduce the likelihood that different results between countries are driven by differences in how the survey is conducted within each country. This reduces our uncertainty about the extent to which differences between creditor and debtor countries reflect actual substantive differences. In order to harmonize survey practices, the ESS developed strict guidelines for consistent methods of fieldwork, including contacting and coding, and the implementation of random sampling. Given the cross-sectional nature of the ESS data, individuals in the sample share common characteristics based on their country of residence and the year of the survey as well as the generation to which they belong. To deal with the issue of nested data, the analysis utilizes pooled regression models with cross-random effects as suggested by Yang and Land (2008). We use random effects for birth cohorts (and age) and country*survey year fixed effects. All models use equilibrated survey weights that adjust for sample and population size differences. The dataset obtained from merging the eight ESS waves entails 303,987 respondents from 27 EU member states. We include countries that at least featured in two survey years. Malta is the only country missing in our sample.

While cohorts are constructed based on the operationalization provided in Table 1, age and a squared term for age are included to estimate linear and curvilinear life-cycle effects. To capture period effects, the interactions between cohorts and being a creditor or debtor state, age and being a creditor or debtor state as well as these interaction at different times in the Eurozone crisis are included. This allows us to explore generational differences and life-cycle effects differ based on the country's experience in the Eurozone crisis. 
To assess the effect of period effects as well as cohort and life-cycle effects on EU support, we rely on two different measures: trust in the European Parliament (EP) as well as support for European unification. These two items are viewed to capture quite distinct aspects of public opinion towards the EU (De Vries 2018), and are only moderately correlated (Pearson's R of 0.34). Following the literature, trust in the EP taps into a more affective and diffuse aspect of support for the EU relating to loyalty to institutions and the rules of the game, while support for the European unification process as such taps into a more specific aspect of support for the degree of cooperation in Europe. Trust in the EP is measured on a scale of 0 'no trust at all' to 10 'complete trust', and support for further unification is measured on a scale from 0 'unification has already gone too far' to 10 'unification should go further'. Other items tapping into more diffuse and specific aspects of support would have been very interesting, but the ESS fails to include them. Based on existing work, we expect trust in the EP and support for unification to decline along the life-cycle, because younger individuals benefit more directly from European integration through better mobility and educational opportunities, whereas individuals are commonly more locally rooted in adulthood due to work and/or family (Down and Wilson 2013, 2017). When it comes to cohort effects, we expect trust in the EP and support for unification to be higher in in younger compared to older cohorts. This is because younger cohorts are socialized in an increasingly integrated context, and therefore less ideologically and affectively bound to traditional institutions (Scherer 2015). Yet, crucial for this study, we expect these life-cycle and cohort effects to differ based on period effects due to the divergent economic impact of the Eurozone crisis. Specifically, we expect that younger generations in debtor states that were most adversely affected by the Eurozone crisis are less trusting of the EU and supportive of European unification compared to younger generations in creditor countries, and the generational divides are overall less pronounced in the debtor countries based on the crisis experience.

To control for alternative explanations, the models include several sociodemographic and socio-economic variables that previous research has identified as important explanations of EU support: gender ( 0 'female'; 1 'male'), placement on the left-right scale (0 'most left' to 10 'most right'), educational level as proxy for skill levels (1 'less than lower secondary education'; 2 'lower secondary education completed'; 3 'upper secondary education completed'; 4 'post-secondary non-tertiary education completed'; 5 'tertiary education completed'), attitudes toward immigration as proxy for exclusive national identities and perceived cultural threat ( 0 most 'negative' to 10 'most positive'), feeling about household income (1 'very difficult on present income' to 4 'living comfortably'), political interest ( 1 'not at all interest' to 4 'very interested') as well as dummies for being catholic, protestant 
and Eastern orthodox ( 0 'no'; 1 'yes') as previous studies have identified religious denominations as predictors of Euroscepticism (e.g., Boomgaarden and Freire 2009).

\section{Empirical analysis}

Table 2 shows the results of the baseline APC regression estimating cohort and life-cycle effects on trust in the EP and support for further unification while controlling for country*survey year variation. The fact that the time periods differ slightly between the two dependent variables, 2002-2016 for trust in EP versus 2004-2016 for support for further unification, is due to data availability. The negative and statistically significant effect of age in both models appears to confirm previous evidence that people become more Eurosceptic as they age and proceed through their life-cycle. This finding is in line with previous research (Down and Wilson 2013, 2017). The results also show clear generational differences. These significant generational differences in levels of trust in the EP and unification support persist when simultaneously controlling for life-cycle and period effects. Trust in the EP is statistically significantly higher in the pre-integration cohort and the EMU cohort relative to the reference group (the post-integration cohort), whereas support for further unification is statistically significantly higher in the EMU cohort. Interestingly, belonging to the post-Maastricht cohort, is not a statistically significant predictor of trust in the EP or support for further unification, which contradicts existing scholarly work (e.g., Down

Table 2. Age, period and cohort effects and public opinion towards the EU.

\begin{tabular}{|c|c|c|}
\hline & $\begin{array}{l}\text { Trust in the EP } \\
\text { 2002-2016 } \\
\text { Beta (Std. Error) }\end{array}$ & $\begin{array}{l}\text { Support for further unification } \\
\text { 2004-2016 } \\
\text { Beta (Std. Error) }\end{array}$ \\
\hline \multicolumn{3}{|l|}{ Cohort } \\
\hline Pre-integration & $.325^{* * *}(.035)$ & $-.049(.046)$ \\
\hline Merger & $-.032(.033)$ & $.056(.043)$ \\
\hline SEA & $.048(.054)$ & $.112(.071)$ \\
\hline Post-Maastricht & $.101(.063)$ & $.186(.082)$ \\
\hline EMU & $.563^{* * *}(.078)$ & $.380 * * *(.101)$ \\
\hline Age & $-.015^{* * *}(.002)$ & $-.008^{* * *}(.002)$ \\
\hline \multicolumn{3}{|l|}{ Period (survey year) } \\
\hline 2004 & $-.248 * * *(.029)$ & \\
\hline 2006 & $-.270 * * *(.030)$ & $-.294^{* * *}(.032)$ \\
\hline 2008 & $-.194^{* * *}(.030)$ & $-.096^{* * *}(.032)$ \\
\hline 2010 & $-.500^{* * *}(.033)$ & \\
\hline 2012 & $-.510^{* * *}(.035)$ & $-.183^{* * *}(.037)$ \\
\hline 2014 & $-.758^{* * *}(.038)$ & $-.497^{* * *}(.040)$ \\
\hline 2016 & $-.584^{* * *}(.041)$ & $-.357^{* * *}(.044)$ \\
\hline Country*Year fixed effects & Yes & Yes \\
\hline$N$ (observations) & 268,881 & 201,795 \\
\hline$R^{2}$ (adjusted) & .032 & .012 \\
\hline
\end{tabular}


and Wilson 2013, 2017; Fox and Pearce 2018). This difference in findings might be driven by the inclusion of Central-East European member states that were not systematically examined in previous analyses. Running the model without post-communist states confirms this intuition as it yields a significantly positive effect for the post-Maastricht cohort. Period effects are significant and negative in every successive period following the baseline year.

Table 3 presents the full APC regression models estimating age, period and cohort effects including the full set of individual-level controls. When we compare the adjusted $R^{2}$ between Tables 2 and 3, we see that adding controls increases the explained variation from 3.2 percentage to 11.9 percentage points in case of trust in the EP and from 1.2 percentage to 14.2 percentage points in case of support for further unification. Even after including controls, there is robust negative and statistically significant effect of age on both measures of EU support. Euroscepticism on average increases along the lifecycle. The positive and statistically significant squared term of age,

Table 3. Age, period and cohort effects and public opinion towards the EU, including controls.

\begin{tabular}{|c|c|c|}
\hline & $\begin{array}{l}\text { Trust in the EP } \\
2002-2016 \\
\text { Beta (Std. Error) }\end{array}$ & $\begin{array}{l}\text { Support for further unification } \\
2004-2016 \\
\text { Beta (Std. Error) }\end{array}$ \\
\hline \multicolumn{3}{|l|}{ Cohort } \\
\hline Pre-integration & $.197^{* * *}(.041)$ & $-.065(.053)$ \\
\hline Merger & $.031(.033)$ & $.059(.043)$ \\
\hline SEA & $.038(.055)$ & $.011(.069)$ \\
\hline Post-Maastricht & $-.014(.066)$ & $.004(.083)$ \\
\hline EMU & $.326^{*}(.086)$ & $.113(.109)$ \\
\hline Age & $-.058^{* * *}(.005)$ & $-.044^{* * *}(.006)$ \\
\hline $\mathrm{Age}^{2}$ & $.000^{* * *}(.000)$ & $.000^{* * *}(.000)$ \\
\hline \multicolumn{3}{|l|}{ Period (survey year) } \\
\hline 2004 & $-.173^{* * *}(.031)$ & \\
\hline 2006 & $-.235^{* * *}(.031)$ & $-.364^{* * *}(.032)$ \\
\hline 2008 & $-.233^{* * *}(.031)$ & $-.299 * * *(.032)$ \\
\hline 2010 & $-.455^{* * *}(.034)$ & \\
\hline 2012 & $-.462^{* * *}(.036)$ & $-.227^{* * *}(.038)$ \\
\hline 2014 & $-.756^{* * *}(.038)$ & $-.556^{* * *}(.039)$ \\
\hline $\begin{array}{l}2016 \\
\text { Controls }\end{array}$ & $-.648^{* * *}(.041)$ & $-.441^{* * *}(.045)$ \\
\hline Gender & $-.231^{* * *}(.014)$ & $.043(.018)$ \\
\hline Left-Right placement & $.031^{* * *}(.004)$ & $-.047^{* * *}(.004)$ \\
\hline Educational level & $.029^{* * *}(.006)$ & $.083^{* * *}(.007)$ \\
\hline Immigration attitudes & $.249^{* * *}(.003)$ & $.378^{* * *}(.005)$ \\
\hline Household income & $.187^{* * *}(.010)$ & $.048^{* * *}(.012)$ \\
\hline Political interest & $.199 * * *(.009)$ & $.105^{* * *}(.012)$ \\
\hline Catholic & $.468^{* * *}(.019)$ & $.557^{* *}(.021)$ \\
\hline Protestant & $.077^{* *}(.023)$ & $-.072(.028)$ \\
\hline Eastern Orthodox & $.989^{* * *}(.068)$ & $.441^{* * *}(.050)$ \\
\hline Country*Year fixed effects & Yes & Yes \\
\hline$N$ (observations) & 225,940 & 172,415 \\
\hline$R^{2}$ (adjusted) & .119 & .142 \\
\hline
\end{tabular}


however, indicates that the relationship between individual aging and Euroscepticism might not be linear, but rather curvilinear with support for the EU increasing again in older age. This finding contrasts previous research showing that support decreasing again with older age (e.g., Lubbers and Jaspers 2011). Yet, this discrepancy is most likely due to the fact that previous analyses did not include Central-East European countries.

For trust in the EP (second column in Table 3), a significant positive cohort effect of the pre-integration cohort and the EMU cohort persists even after the inclusion of controls. In other words, Europe's oldest and youngest generations are more trusting of the EP than the post-integration cohort (second oldest generation), whereas all other cohorts did not display statistically significant differences compared to the reference group, the post-integration cohort. Regarding support for further unification (third column in Table 3), cohort effects are statistically insignificant suggesting that there is no difference between generations in their preference for further unification. Period effects are also very similar to those identified in the baseline model in Table 2. Trust in the EP and support for further unification has significantly decreased in every survey year compared to the first examined wave with almost every successive cohort being characterized by a more negative beta coefficient up to 2014 .

So far, in line with most of the literature, we found a statistically significant and negative life-cycle effect on trust in the EP and support for further unification. Second, the life-cycle effect was curvilinear, with support for the EU decreasing as respondents go from childhood to late adulthood, and becoming slightly more supportive again in older age. While this contradicts some of the existing literature, it is likely to due to fact that previous work did not include Central-East European member states. The results furthermore revealed that the most recent cohort (those born after 1979) are more positive toward the EP compared to older cohorts, but that no difference exists in preferences for further unification. The results so far are based on simultaneously analyzing various EU member states with diverse backgrounds and outlooks. To explore possible contextual variation and the role of different experiences with the Eurozone crisis, we now turn to patterns among Euro-creditor and -debtor member states.

Figure 1 shows the average predicted margins for trust in the EP (left) and support for further unification (right) by age and debtor-creditor status. The graphs are based on a model that now includes an interaction term between age and being a creditor, debtor member state or other.

Three things stand out. First, both figures clearly highlight the curvilinear lifecycle effect with declining levels of EP trust as well as support for further unification approximately within the first fifty years of an individual's life, yet increasing again at older age. This pattern is evident in all groups of countries as well as for both dependent variables. Second, there are more differences between 
Trust in the EP (2002-2016)

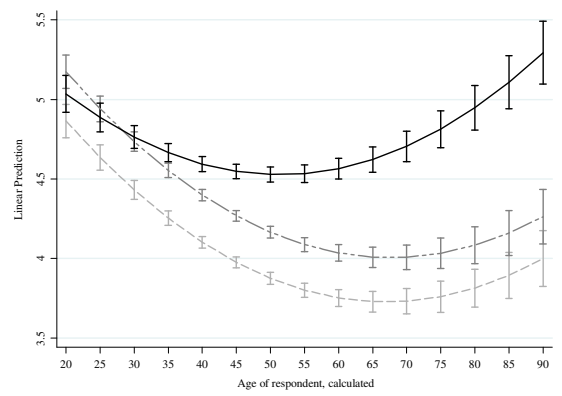

Other EU member states

Euro-debtor member states
Support for further unification (2004-2016)

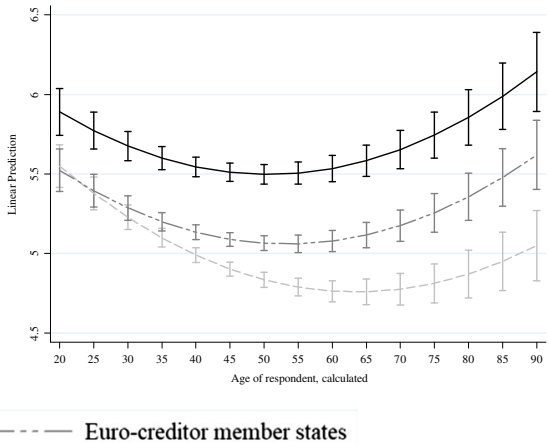

Figure 1. Marginal means by age, Euro-debtor, Euro-creditor and other EU member states.

Notes: Regression results depicted in Table 1 in Appendix.

debtor and creditor countries in levels of support for the EU among older respondents. This divergence is particularly pronounced in case of trust in the EP and between debtor vis-à-vis creditor and other member states. Third, while debtor countries are on average more supportive of the EU, both in terms of trust and further unification, compared to other country groups, which is in line with existing work on EU public opinion (De Vries 2018), generational divides are less pronounced in debtor-countries. When it comes to trust in the EP or support for further unification, there are virtually no significant differences in marginal means between the young and elderly within debtor countries (identifiable by overlapping confidence intervals). For debtors, the lack of significant differences between generations is also apparent in case of trust in the EP (left-hand figure), whereas levels of trust are significantly lower among older age groups relative to the younger ones in creditor and other member states. We find more generational differences for creditor countries especially, although these differences between generations are more pronounced in the case of trust in the EP (left-hand figure).

These results support the idea that the Eurozone crisis might have had differential effects on generational differences. While much of the previous work has explicitly or implicitly assumed that spatial variation in preferences toward the EU is not relevant when it comes to explaining generational divides, our result suggest that regional divides are important. To explore this issue further and identify intra- and intergenerational divides between different regions, we add an interaction term between the cohort and the creditor-debtor variable to the full APC model. The results in Figure 2 depict average predicted margins to enhance interpretation. Specifically, it shows 
Trust in the EP (2002-2016)

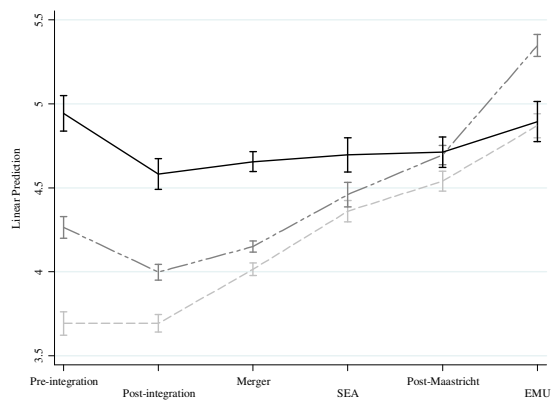

Other EU member states Euro-debtor member states
Support for further unification (2004-2016)

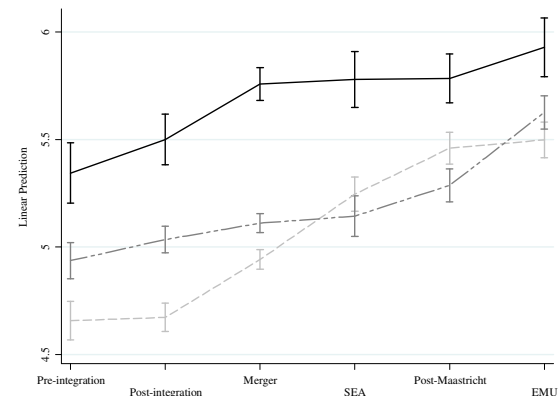

Euro-creditor member states

Figure 2. Marginal means by cohort, Euro-debtor, Euro-creditor and other EU member states.

Notes: Regression results depicted in Table 2 in Appendix.

adjusted predictions for trust in the EP and support for further unification by cohort and creditor-debtor status at observed values.

Two things stand out here. First, in the non-debtor member states, that is to say creditor and other member states, trust in the EP increases across every successive cohort following the post-integration cohort and are statistically significant. This is not the case for successive cohorts in debtor states that are not significantly distinct from one another. Similar patterns emerge for further unification support, albeit less pronounced. Interestingly, while there is virtually no significant difference between debtor cohorts in case of trust in the EP (in contrast to the significant differences in successive creditor cohorts), support for further unification is significantly higher in the EMU cohort relative to the post-integration cohort in debtor states (similar patterns can be identified in creditor and other member states).

Second, trust in the EP is significantly higher in debtor states among almost all cohorts with the EMU cohort being the only exception. Older debtor cohorts are significantly more trustful than their counterparts in creditor member states and the remaining EU. Yet, this gap diminishes in every successive cohort and ultimately results in a significantly more sceptical EMU cohort in debtor countries relative to the same cohort in non-debtor states. Support for further unification, on the other hand, is significantly higher among all cohorts in debtor member states relative to the other two other groups of member states. Overall, these findings underline the idea that considerable regional variation in generational patterns in support for the EU exists. While the patterns of generational differences are largely similar in creditor and other EU member states, cohorts in debtor states are characterized by 
very different generational trends - particularly regarding trust in the EP, where younger cohorts are not more positive compared to older cohorts.

To what extent are these different patterns in cohort effects between debtor member states vis-à-vis creditor and other member states a result of the Eurozone crisis? To explore this question, we interacted the crisis experience of creditor and debtor member states with the cohort variable. Results are again depicted as adjusted predictions at observed values in Figures 3 and 4.

Trust in the EP (2002-2016)

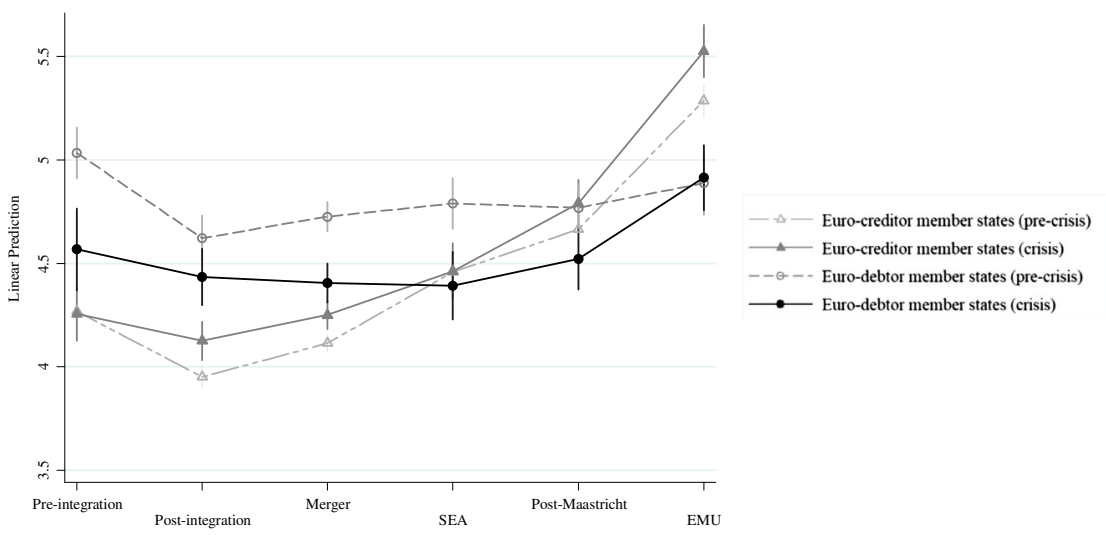

Figure 3. Marginal means by cohort, Euro-creditor pre-crisis (before 2008) and in crisis (2008-2012), Euro-debtor pre-crisis (before 2008) and in crisis (2008-2012).

Notes: Regression results depicted in Table 3 in Appendix.

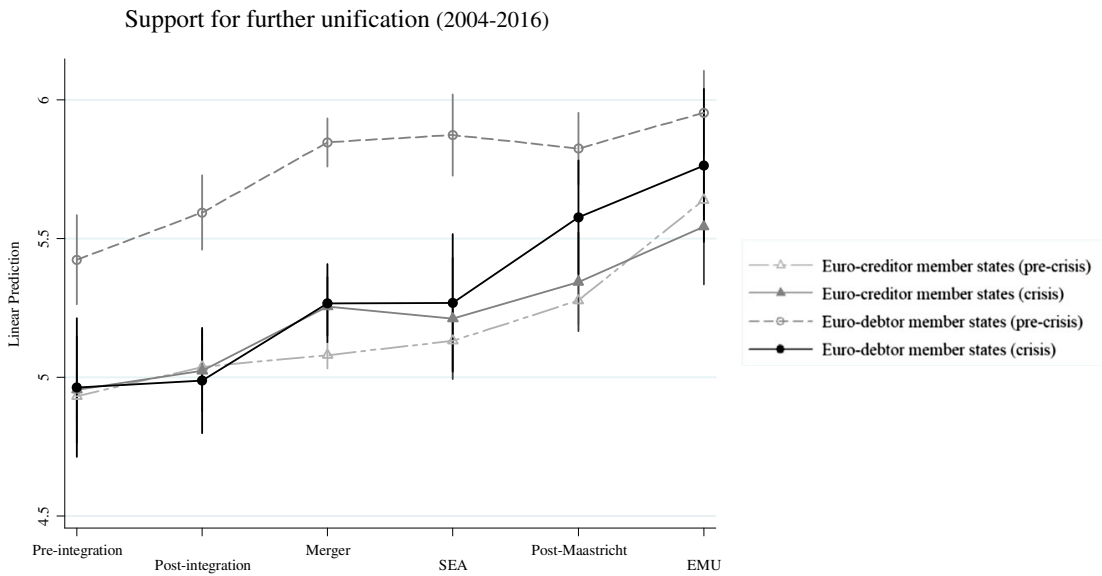

Figure 4. Marginal means by cohort, Euro-creditor pre-crisis (before 2008) and in crisis (2008-2012), Euro-debtor pre-crisis (before 2008) and in crisis (2008-2012).

Notes: Regression results depicted in Table 3 in Appendix. 
When it comes to trust in the EP, the first result that stands out is that the effect of the EMU cohort in debtor member states is not significantly different in the Eurozone crisis period compared to the pre-crisis period. The pre-integration cohort, the Merger cohort, the SEA cohort as well as the post-Maastricht cohort, however, placed significantly more trust in the EP in debtor states compared to the same cohorts in creditor states before the crisis, whereas levels of trust are not significantly different during the Eurozone crisis period. Interestingly, while the Eurozone crisis period generally lowered levels of trust across all debtor cohorts, and these effects are statistically significant (the only exception being the EMU cohort), levels of trust during the crisis period increased in the post-integration, Merger, and EMU cohort of creditor member states.

The adjusted predictions for unification support across cohorts in creditor and debtor member states before and during the Eurozone crisis paint an even more interesting picture. While every cohort in debtor states has been significantly more supportive than the same cohort in creditor states prior to the crisis, these significant differences diminish during the Eurozone crisis period. There is virtually no difference between cohorts of creditor and debtor cohorts in the crisis period. While on both measures EU support increase during the Eurozone crisis in creditor member states, the opposite pattern emerges for debtor states. There is no significant effect on support for further unification in the EMU cohort in the pre-crisis period in debtor countries. In both creditor and debtor member states, however, a significant negative effect emerges as the Eurozone crisis unfolds. Overall, the impact of the crisis on cohort effects varies considerably across both, the examined regions (debtor versus creditor) as well as cohorts.

Most notably, while the previous analysis has hardly uncovered any cohort effects on support for further unification, the difference between debtor and creditor member states before and during the crisis reveals that the Eurozone crisis period is characterized by several negative and statistically significant cohort effects that did not exist, or were very small, during the pre-crisis period. In creditor member states, there is a significantly more pronounced negative cohort effect identifiable for the Merger, SEA, post-Maastricht and EMU cohort in the crisis period compared to before the crisis. In debtor member states, on the other hand, the negative effect of the SEA and postMaastricht cohort has become less pronounced from the pre-crisis to the crisis period, whereas the Eurozone crisis coincides with a considerable negative cohort effect in the EMU cohort (which had no significant impact on unification support prior to the crisis).

Taken together, the results demonstrate that European citizens of similar age or within similar cohorts display different levels of trust in the EP or support for European integration in different regions. The analysis also shows that younger generations in debtor member states are relatively less 
enthusiastic about the EU since the Eurozone crisis unfolded and that an intragenerational divide between citizens in debtor and creditor member states exists. Young generations are considerably more in favour of European integration than adults in creditor states, while young generations are no longer different from older generations in debtor states. While the most recent generation in debtor states is relatively more negative than sameaged individuals in creditor states, the reverse is true for older generations, especially when it comes to trust in the EP.

\section{Concluding remarks}

This study aimed to demonstrate that the predominant view that younger European generations are more supportive of the EU compared to older generations is not a uniform Union-wide phenomenon. Rather it varies considerably across member states. This suggests that our thinking and theorizing about generational divides should be contextualized. This study has drawn our attention to the Eurozone crisis. The evidence suggests that the youth in Southern member states is more sceptical of the EU and its institutions than the youth in creditor states, whereas the opposite is true for previous cohorts. Based on this empirical evidence presented here, the hope for 'a rising generation of Europeans' appears to be far from a pan-European phenomenon. The results also illustrate how the steadily increasing politicization of EU membership from the Maastricht Treaty, that effectively ended the permissive consensus on the formerly elite-driven unification process (Hobolt and De Vries 2016), to the Eurozone crisis has not necessarily led to a more supportive youth (Down and Wilson 2013, 2017).

The empirical evidence presented in this study tempers widespread optimism that Euroscepticism will gradually disappear simply with the passing of time through generational replacement. What we find, however, is that younger generations in Euro-debtor states are increasingly sceptical about the EU and its institutions relative to the same-aged individuals in Euro-creditor states. Given that the publics of Southern Europe have been and still are the main drivers of public support for the EU, these results are especially important. They mitigate the often-proclaimed bright outlook for European integration with a significant source of opposition and attachment to the nation state being eroded through generational replacement. The results presented here suggest that this will crucially depend on the experiences that young generations make with the EU. As the Eurozone crisis increased youth unemployment in the South, younger generations became more critical toward the EU.

The evidence could also imply that support for the EU can become more volatile in the future as younger generations, who were socialized in an environment of crisis, are more likely to question the fruits of European 
integration. This study has drawn attention to the fact that generational divides are often context-dependent. That said, it is important to remember that it is still an open question if the current differences between creditor and debtor states will persist. This is an important area for future research concerning public opinion towards European integration.

\section{Notes}

1. https://www.theguardian.com/politics/2016/jun/26/young-people-vote-anger.

2. https://www.independent.co.uk/news/nearly-half-young-french-voters-marinele-pen-emmanuel-macron-french-election-2017-a7723291.html.

3. https://www.prospectmagazine.co.uk/world/are-younger-voters-really-the-bestdefence-against-populism.

4. Speech by Mario Draghi on 22nd of September 2017: https://www.ecb.europa. eu/press/key/date/2017/html/ecb.sp170922_1.en.html.

5. We use the terms age cohort and generation interchangeably to signify a group of people who share a specific bracket of years in which they were born, and thus share certain formative experiences.

6. https://europa.eu/youth/es/article/39/43629_en.

7. Euro-creditor countries were defined as either a creditor Austria, Belgium, Finland, France, Germany, and the Netherlands, Euro-debtor as Cyprus, Greece, Italy, Portugal, and Spain, and the remaining member states as other.

\section{Disclosure statement}

No potential conflict of interest was reported by the authors.

\section{Biographical notes}

Fabian Lauterbach holds a Master Degree in Political Science from the VU University Amsterdam and now works in the private sector.

Catherine E. De Vries is a Professor of Politics at Bocconi University in Milan. She is the author of the prize-winning book Euroscepticism and the Future of European Integration with Oxford University.

\section{References}

Boomgaarden, H.G. and Freire, A. (2009) 'Religion and euroscepticism: direct, indirect or no effects?' West European Politics 32(6): 1240-65.

Daniele, G. and Geys, B. (2015) 'Public support for European fiscal integration in times of crisis', Journal of European Public Policy 22(5): 650-70.

De Vries, C.E. (2018) Euroscepticism and the Future of European Integration, Oxford: Oxford University Press.

Dinas, E. and Stoker, L. (2014) 'Age-period-cohort analysis: a design-based approach', Electoral Studies 33: 28-40.

Down, I. and Wilson, C.J. (2013) 'A rising generation of Europeans? Life-cycle and cohort effects on support for 'Europe", European Journal of Political Research 52(4): 431-56. 
Down, I. and Wilson, C.J. (2017) 'A rising generation of Europeans? Revisited', European Journal of Political Research 56(1): 199-214.

Fligstein, N. (2008) Euroclash: The EU, European Identity, and the Future of Europe, Oxford: Oxford University Press.

Ford, R. and Goodwin, M. (2014) 'Understanding UKIP: identity, social change and the left behind', The Political Quarterly 85(3): 277-84.

Fox, S. and Pearce, S. (2018) 'The generational decay of Euroscepticism in the UK and the EU referendum', Journal of Elections, Public Opinion and Parties 28(1): 19-37.

Gabel, M.J. (1998) 'Economic integration and mass politics: market liberalization and public attitudes in the European Union', American Journal of Political Science 42: 936-53.

Grasso, M.T. (2014) 'Age, period and cohort analysis in a comparative context: political generations and political participation repertoires in Western Europe', Electoral Studies 33: 63-76.

Hakhverdian, A., Van Elsas, E., Van der Brug, W. and Kuhn, T. (2013) 'Euroscepticism and education: a longitudinal study of 12 EU member states, 1973-2010', European Union Politics 14(4): 522-41.

Hobolt, S.B. and De Vries, C.E. (2016) 'Public support for European integration', Annual Review of Political Science 19: 413-32.

Hooghe, L. and Marks, G. (2009) 'A postfunctionalist theory of European integration: from permissive consensus to constraining dissensus', British Journal of Political Science 39(1): 1-23.

Inglehart, R. (1971) 'The Silent Revolution in Europe: Intergenerational Change in PostIndustrial Societies', American Political Science Review 65(4): 991-1017.

Inglehart, R. (1984) 'Generational change and the future of the Atlantic Alliance', Political Science \& Politics 17(3): 525-35.

Jennings, M.K. (2007) 'Political socialization', in R.J. Dalton (ed.), The Oxford Handbook of Political Behavior, Oxford: Oxford University Press, pp. 22-44.

Jennings, M.K., Stoker, L. and Bowers, J. (2009) 'Politics across generations: family transmission reexamined', The Journal of Politics 71(3): 782-99.

Jung, J.K. (2008) 'Growing supranational identities in a globalising world? A multilevel analysis of the World Values Surveys', European Journal of Political Research 47(5): 578-609.

Keating, A. (2014) Education for Citizenship in Europe: European Policies, National Adaptations and Young People's Attitudes, London: Palgrave Macmillan, UK.

Lefkofridi, Z. and Schmitter, P.C. (2015) 'Transcending or descending? European integration in times of crisis', European Political Science Review 7(1): 3-22.

Lubbers, M. and Jaspers, E. (2011) 'A longitudinal study of euroscepticism in the Netherlands: 2008 versus 1990', European Union Politics 12(1): 21-40.

Lubbers, M. and Scheepers, P. (2005) 'Political versus instrumental Euro-scepticism: mapping scepticism in European countries and regions', European Union Politics 6 (2): 223-42.

Lubbers, M. and Scheepers, P. (2010) 'Divergent trends of euroscepticism in countries and regions of the European Union', European Journal of Political Research 49(6): 787-817.

McLaren, L.M. (2002) 'Public support for the European Union: cost/benefit analysis or perceived cultural threat?' The Journal of Politics 64(2): 551-66.

Neundorf, A. and Niemi, R.G. (2014) 'Beyond political socialization: new approaches to age, period, cohort analysis', Electoral Studies 33: 1-6. 
Otjes, S. and Katsanidou, A. (2017) 'Beyond Kriesiland: EU Integration as a Super Issue after the Eurocrisis', European Journal of Political Research 56(2): 301-319.

Scherer, M. (2015) 'The religious context in explaining public support for the European Union', JCMS: Journal of Common Market Studies 53(4): 893-909.

Wilson, I. (2011) 'What should we expect of 'Erasmus generations'?' JCMS: Journal of Common Market Studies 49(5): 1113-40.

Yang, Y., Fu, W.J. and Land, K.C. (2004) 'A methodological comparison of age-periodcohort models: the intrinsic estimator and conventional generalized linear models', Sociological Methodology 34(1): 75-110.

Yang, Y. and Land, K.C. (2008) 'Age-period-cohort analysis of repeated cross-section surveys: fixed or random effects?' Sociological Methods \& Research 36(3): 297-326.

Yang, Y.C. and Land, K. (2016) Age-Period-Cohort Analysis: New Models, Methods, and Empirical Applications, Chapman and Hall/CRC. 